УДК 930.25:35.088

DOI https://doi.org/10.31470/2518-7600-2019-7-47-67

RESEARCHES OF THE PECULIARITIES OF LABOR ORGANIZATION AND MANAGEMENT IN THE ARCHIVAL INSTITUTIONS IN UKRAINE: THEORETICAL PRACTICES AND PRACTICAL EXERCISE

\title{
ДОСЛІДЖЕННЯ ОСОБЛИВОСТЕЙ ОРГАНІЗАЦЇ ПРАЦІ Й УПРАВЛІННЯ В АРХІВНИХ УСТАНОВАХ УКРАЇНИ: ТЕОРЕТИЧНІ ЗАСАДИ ТА ПРАКТИЧНЕ ВТІЛЕННЯ
}

\section{ИССЛЕДОВАНИЕ ОСОБЕННОСТЕЙ ОРГАНИЗАЦИИ ТРУДА И УПРАВЛЕНИЯ В АРХИВНЫХ УЧРЕЖДЕНИЯХ УКРАИНЫ: ТЕОРЕТИЧЕСКИЕ ОСНОВЫ И ПРАКТИЧЕСКАЯ РЕАЛИЗАЦИЯ}

\section{Людмила Дідух,}

кандидат історичних наук, завідувач відділу технологічного забезпечення архівної справи d-lv@ukr.net

Український науково-дослідний інститут архівної справи та документознавства (УНДІАСД) вул. Солом'янська, 24, м. Київ, Україна, 03110

Оксана Гула, кандидат історичних наук, старший науковий співробітник відділу технологічного забезпечення архівної справи ksenjagula@gmail.com orcid.org/0000-0001-5437-9042 Український науково-дослідний інститут архівної справи та документознавства (УНДІАСД) вул. Солом'янська, 24, м. Київ, Україна, 03110
Lyudmila Didukh, candidate of historical sciences, Head of the Department of archival affair technological providing d-lv@ukr.net

The Ukrainian Research Institute of Archival Affairs and Record Keeping (URIAARK)

Solomyanska st., 24, Kyiv, Ukraine, 03110

\section{Oksana Gula,}

candidate of historical sciences, Senior researcher of the Department of archival affair technological providing ksenjagula@gmail.com orcid.org/0000-0001-5437-9042 The Ukrainian Research Institute of Archival Affairs and Record Keeping (URIAARK)

Solomyanska st., 24, Kyiv, Ukraine, 03110 


\section{ABSTRACT}

The article analyzes normative-legal, scientific-methodical and legislative documents, provisions of which regulate the activity of archival institutions in Ukraine. The peculiarities of the organization of labor and management in archival institutions, the content of the existing professions of their employees are investigated. The modern changes in archival technologies, conditions of organization of work and requirements to the professional qualification levels of employees are studied. According to the results, outdated types of work that are not defined in archives (film manifestation, light and color setting in process of film copies processing, preparation of original film materials). A list of new types of archival activity, dictated by changes in approaches to the organization of work and use of working time, more productive cooperation between archivists and archives users, effective protection of electronic archival documents are compiled (knowledge of the bases of using computer technology, one or several foreign languages, knowledge of the laws, economy, management, finance, use of the latest domestic and foreign experience). The features of the content of existing and new types of works (professions) of the archival sphere employees are determined. A list of the main qualification characteristics of workers professions employed in the archival case is formed and it is established that their application is obligatory for the assignment of qualifications (categories), defines the main works, which are specific to one or another position (profession), provides unity in determining the qualification requirements to certain occupations, allows to assess the completeness of the content and quality of performance of work by the employee in a certain position (a certain profession) of the relevant category during the qualification tests. Proposed own vision of tasks and responsibilities, qualification requirements and requirements to the level of knowledge for the positions (professions) of archival institution employees. On the basis of this, a new version of the normative document, which is obligatory for use in archival institutions is developed - the Handbook of qualification characteristics of employees professions. Issue 81 «Culture and Art». Section «The archives activity». 
Keywords: archival institution, Handbook, document, description, requirements, position, employee.

Постановка проблеми. Організація праці й управління в архівних установах $\epsilon$ системою здійснення трудового процесу, що характеризується внутрішньою упорядкованістю, узгодженістю та спрямованістю взаємодії працівників для реалізації спільної мети та забезпечення заданого соціальноекономічного ефекту. Втім серед компонентів такої організації праці важливе місце посідає удосконалення їі умов і змістовне підвищення якості технологічних процесів, реалізація трудового потенціалу працівника, оптимізація особистісних взаємин у процесі трудової діяльності. Зазначені показники мають бути відображені у кваліфікаційних характеристиках професій працівників архівів усіх форм власності. Кваліфікаційна характеристика визначає перелік основних робіт, властивих тій або іншій професійній назві роботи (посаді, професії), відповідно до їхніх назв і забезпечує єдність у визначенні кваліфікаційних вимог до них.

У 2018 р. на замовлення Державної архівної служби України Український науково-дослідний інститут архівної справи та документознавства виконував науково-дослідну роботу «Дослідження особливостей організації праці й управління в архівних установах 3 метою визначення відповідальності, компетентності, функцій та повноважень їх працівників». Мета дослідження - визначення компетентності, функцій та повноважень, відповідальності, вимог до рівня знань працівників архівних установ.

Для досягнення поставленої мети необхідно було вирішити наступні завдання: проаналізувати чинну нормативно-правову базу, що регламентує організацію праці в архівних установах; дослідити особливості управління в архівних установах; здійснити перегляд, удосконалення чинних кваліфікаційних характеристик 3 урахуванням освоєння новітніх технологій; встановити кваліфікаційні вимоги та вимоги до рівня знань для певних посад (професій) архівних працівників. 
Аналіз останніх досліджень і публікацій. На сьогоднішній день питання аналізу компетентності, повноважень, відповідальності архівних працівників ще не стало об’єктом спеціальних наукових досліджень.

Тому, щоб юридично правильно, чітко регламентувати права й обов'язки усіх учасників трудових відносин в архівних установах, встановити особливості організації праці й управління в архівах було проаналізовано низку нормативноправових документів. Зокрема, Конституцію України (Конституція, 1996), яка статтею 43 проголошує право на працю; Закон України «Про зайнятість населення» (Про зайнятість, 2012), що визначає правові, економічні й організаційні основи зайнятості населення та його захист від безробіття, а також соціальні гарантії з боку держави в реалізації громадянами права на працю; положення Закону України «Про оплату праці» (Про оплату, 1995), що визначають економічні, правові та організаційні засади оплати праці працівників, які перебувають у трудових відносинах на підставі трудового договору з підприємствами усіх форм власності та господарювання; Закон України «Про охорону праці» (Про охорону, 1992), що визначає реалізацію конституційного права громадян на охорону їхнього життя та здоров'я у процесі трудової діяльності, регулює за участю відповідних державних органів відносини між власником підприємства й працівником 3 питань безпеки, гігієни праці та виробничого середовища та встановлює єдиний порядок організації охорони праці в Україні.

Було вивчено чинні Закони України «Про Національний архівний фонд та архівні установи» (Про Національний архівний фонд, 1993), «Про освіту» (Про освіту, 2017), «Про вищу освіту» (Про вищу освіту, 2014), «Про професійнотехнічну освіту» (Про професійно-технічну освіту, 1998), а їхні положення використано при практичному втіленні результатів дослідження.

Важливим джерелом послугували Методичні рекомендації щодо формування кваліфікаційних характеристик, затверджених наказом Міністерства соціальної політики України та Міністерства освіти і науки, молоді та 
спорту України (Про затвердження..., 2011), а також Порядок розроблення та затвердження кваліфікаційних характеристик, затверджений Наказом Мінсоцполітики України (Про затвердження..., 2017). Ці документи є базовими для підготовки кваліфікаційних характеристик і визначають процедуру розроблення, погодження, затвердження кваліфікаційних характеристик професій працівників.

У роботі використовувався Національний класифікатор України «Класифікатор професій» ДК 003:2010 (Класифікатор, 2010), що стандартизує назви категорій персоналу, професій та посад.

Практичним втіленням дослідження особливостей організації праці й управління в архівних установах України, а також визначення відповідальності, компетентності, функцій та повноважень архівних працівників стало укладання нової редакції Довідника кваліфікаційних характеристик професій працівників. Випуск 81 «Культура та мистецтво». Розділ «Діяльність архівів» (далі - ДКХП).

ДКХП. Випуск 81 «Культура та мистецтво». Розділ «Діяльність архівів»є нормативним документом, обов' язковим для управління персоналом в архівних установах. Він забезпечує створення і функціонування галузевої нормативної бази 3 організації праці та професійної класифікації, раціональний розподіл праці, формування дієвого механізму розмежування функцій, повноважень і відповідальності, чітку регламентацію трудової діяльності працівників у сучасних суспільно-економічних умовах.

ДКХП підготовлений з урахуванням змін до завдань та обов'язків, кваліфікаційних вимог до персоналу в сучасних умовах господарювання і одночасно зберігає наступність, послідовність, традиції застосування та особливості побудови кваліфікаційних характеристик працівників архівних установ, які були встановлені попереднім випуском ДКХП. Проте його було підготовлено понад десять років тому, у 2008 р. (Довідник, 2008). За цей час відбулися суттєві зміни в архівних технологіях, умовах праці та вимогах до професійнокваліфікаційних рівнів працівників архівних установ, що зумовило необхідність перегляду кваліфікаційних 
характеристик та актуалізувало оновлення переліку вимог до знань, умінь та кваліфікації архівних працівників.

Крім того, положення нової редакції ДКХП:

- визначають перелік основних робіт, які властиві тій або іншій посаді (професії), та забезпечують єдність у визначенні кваліфікаційних вимог до певних посад (професій);

- передбачають ведення відповідної документації при прийнятті на роботу, професійному просуванні, переведенні на іншу роботу, відстороненні від роботи, припиненні та розірванні трудового договору;

- дають змогу оцінити повноту відповідності змісту та якості виконання робіт працівником на певній посаді (певної професії) відповідної категорії під час кваліфікаційних випробувань 3 урахуванням вимог законодавства 3 охорони праці;

- слугують основою для розроблення робочих (посадових) інструкцій, у яких закріплюються завдання, обов'язки, права та відповідальність працівників, а також підготовки положень про структурні підрозділи; підбору та розміщення персоналу; моніторингу раціональності використання персоналу згідно 3 професією (посадою), фахом і кваліфікацією;

- встановлюють порядок вимог до структури та змісту кваліфікаційних характеристик, a також порядку їх розроблення, погодження та затвердження.

До нової редакції ДКХП включено кваліфікаційні характеристики професій керівників, професіоналів, технічних службовців, робітників, що є типовими для архівної галузі. Пропонований перелік назв посад (професій) працівників архівних установ у проекті ДКХП. Випуск 81 «Культура та мистецтво». Розділ «Діяльність архівів» (Видання друге, доопрацьоване) виглядає наступним чином: 


\begin{tabular}{|c|c|c|c|}
\hline І. Керівники & II. Професіонали & $\begin{array}{l}\text { III. Технічні } \\
\text { службовці }\end{array}$ & IV. Робітники \\
\hline $\begin{array}{l}\text { 1.1 Головний } \\
\text { археограф } \\
\text { 1.2 Головний } \\
\text { архівіст } \\
\text { 1.3 Головний } \\
\text { зберігач фондів } \\
\text { 1.4 Головний } \\
\text { методист } \\
\text { 1.5 Головний } \\
\text { палеограф } \\
\mathbf{1 . 6} \text { Директор } \\
\text { державного архіву } \\
\text { 1.7 Директор } \\
\text { Державного центру } \\
\text { збереження } \\
\text { документів } \\
\text { Національного } \\
\text { архівного фонду } \\
\mathbf{1 . 8} \text { Директор } \\
\text { Дирекції з } \\
\text { експлуації } \\
\text { комплексу споруд } \\
\text { центральних } \\
\text { держаних архівних } \\
\text { установ України } \\
\mathbf{1 . 9} \text { Завідувач } \\
\text { архівосховища } \\
\mathbf{1 . 1 0} \text { Завідувач } \\
\text { (начальник) відділу } \\
\text { (сектору) давніх } \\
\text { актів } \\
\mathbf{1 . 1 1} \text { Завідувач } \\
\text { (начальник) відділу } \\
\text { (сектору) } \\
\text { довідкового апарату }\end{array}$ & $\begin{array}{l}\text { 2.1 Археограф } \\
\text { (провідний } \\
\text { археограф, } \\
\text { археограф I } \\
\text { категорії, археограф } \\
\text { II категорії, } \\
\text { археограф) } \\
\text { 2.2 Архівіст } \\
\text { (провідний архівіст, } \\
\text { архівіст I категорії, } \\
\text { архівіст II категорії, } \\
\text { архівіст) } \\
\text { 2.3 Головний } \\
\text { науковий } \\
\text { співробітник } \\
\text { 2.4 Зберігач фондів } \\
\text { (старший зберігач } \\
\text { фондів, зберігач } \\
\text { фондів) } \\
\text { 2.5 Методист } \\
\text { (провідний } \\
\text { методист, методист I } \\
\text { категорії, методист } \\
\text { ІІ категорії, } \\
\text { методист) } \\
\text { 2.6 Молодший } \\
\text { науковий } \\
\text { співробітник } \\
\text { 2.7 Науковий } \\
\text { співробітник } \\
\text { (провідний науковий } \\
\text { співробітник, } \\
\text { старший науковий } \\
\text { співробітник, } \\
\text { науковий } \\
\text { співробітник) } \\
\text { 2.8 Палеограф } \\
\text { (провідний }\end{array}$ & $\begin{array}{l}\text { 3.1 Реставратор } \\
\text { фільмокопій } \\
\text { 3.2 Оператор } \\
\text { копіювальних і } \\
\text { розмножувальних } \\
\text { машин }\end{array}$ & $\begin{array}{l}\text { 4.1 Палітурник } \\
\text { документів } \\
\text { 4.2 Реставратор } \\
\text { архівних та } \\
\text { бібліотечних } \\
\text { матеріалів }\end{array}$ \\
\hline
\end{tabular}




\subsection{2 Завідувач} (начальник) відділу (сектору) забезпечення збереженості документів

\subsection{3 Завідувач} (начальник) відділу (сектору) інформаційних технологій та захисту інформації

1.14 Завідувач (начальник) відділу (сектору) консерваційнореставраційного оброблення документів

1.15 Завідувач (начальник) відділу (сектору) користування документами архіву та використання архівної інформації

1.16 Завідувач (начальник) відділу (сектору) науковометодичної роботи

\subsection{7 Завідувач} (начальник) відділу (сектору) обліку документів

\subsection{8 Завідувач} (начальник) відділу (сектору) оправлення документів

1.19 Завідувач (начальник) відділу (сектору) створення страхового фонду документів палеограф, палеограф I категорії, палеограф II категорії, палеограф)

2.9 Провідний реставратор архівних та бібліотечних матеріалів

2.10 Провідний реставратор фільмокопій 


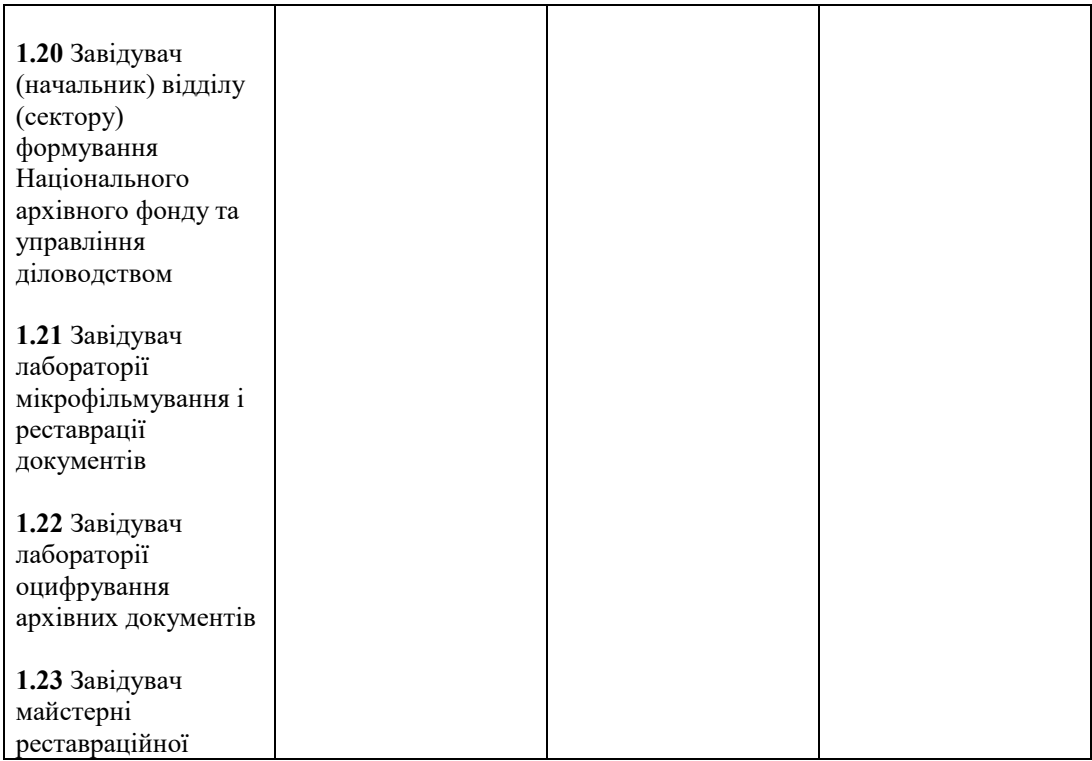

Зазначимо, що на початковому етапі дослідження планувалося згрупувати перелік посад керівних кадрів архівної сфери під назвою «Посади керівних працівників державних архівів та інших архівних установ». До цього переліку було включено такі посади (професіі):

Директор державного архіву; Директор Державного центру збереження документів НАФ; Директор Дирекції 3 експлуатації комплексу споруд центральних держаних архівних установ України; Завідувач архівосховища; Завідувач відділу (сектору) формування НАФ; Завідувач відділу (сектору) обліку документів; Завідувач відділу (сектору) забезпечення збереженості документів; Завідувач відділу (сектору) довідкового апарату; Завідувач відділу (сектору) користування документами архіву та використання архівної інформації; Завідувач відділу (сектору) інформаційних технологій; Завідувач відділу (сектору) науково-методичної роботи; Завідувач відділу (сектору) давніх актів; Завідувач реставраційної майстерні; Завідувач лабораторії мікрофільмування і реставрації документів; Головний зберігач 
фондів; Головний інженер; Головний архівіст; Головний археограф; Головний палеограф; Головний методист.

Однак після консультацій зі спеціалістами Науководослідного інституту праці і зайнятості населення та представниками державних архівних установ України перелік посад керівних кадрів згруповано під назвою «Керівники». 3 цього списку виключено кваліфікаційні характеристики посад працівників: Завідувач фільмотеки, Завідувач фонотеки. Підстава: такі посади відсутні у чинних структурах архівних установ, у штатних розписах архівів і є застарілими. Такі посади більше притаманні для студій та бібліотек.

Натомість до доопрацьованого випуску ДКХП внесли нові кваліфікаційні характеристики посад працівників, які прямо чи опосередковано зайняті в архівних установах: Головний археограф, Головний методист, Головний палеограф, Завідувач (начальник) відділу (сектору) консерваційнореставраційного оброблення документів, Завідувач (начальник) відділу (сектору) науково-методичної роботи, Завідувач (начальник) відділу (сектору) оправлення документів, Завідувач (начальник) відділу (сектору) створення страхового фонду документів, Завідувач лабораторії оцифрування архівних документів.

За градацією групу працівників архівної сфери планувалося об’єднати під загальною назвою «Посади професіоналів і фахівців архівних установ» та включити до неї наступні посади: Головний науковий співробітник; Провідний науковий співробітник; Старший науковий співробітник; Науковий співробітник; Молодший науковий співробітник; Провідний: архівіст, археограф, палеограф, методист, реставратор архівних та бібліотечних матеріалів, реставратор фільмових матеріалів, реставратор фільмокопій; Провідний: інженер, бухгалтер, економіст, юрисконсульт; Архівіст, археограф, палеограф, методист, редактор I категорії, II категорії; Інженер, бухгалтер, економіст, юрисконсульт I категорії, II категорії; Архівіст, археограф, палеограф; Провідний: бібліотекар, бібліограф; Бібліотекар, бібліограф: I категорії, II категорії; Бібліотекар, бібліограф. 
Проте після аналізу законодавчої бази вирішено назвати групу «Професіонали» та включити до неї нові посади: Провідний реставратор архівних та бібліотечних матеріалів, Провідний реставратор фільмокопій. Натомість у цій професійній групі було удосконалено характеристику посади (професії) «науковий співробітник»: до неї додали посади провідного наукового співробітника, старшого наукового співробітника як такі, що подібні за професійними ознаками та не $є$ первинними і кардинально відрізняються лише у розділі «Кваліфікаційні вимоги».

Наступний розділ ДКХП планувалося назвати «Посади (професіі) керівників інших структурних підрозділів і технічних службовців архівних установ» та включити сюди посади реставратора фільмокопій, завідувача фільмотеки, фонотеки. Проте він отримав назву «Технічні службовці», а також було вирішено включити до цього розділу посаду оператора копіювальних і розмножувальних машин. Посаду введено відповідно до діючої схеми тарифних розрядів працівників архівів (Про умови оплати, 2011) та діючого Національного класифікатора професій.

Останній розділ спочатку називався «Посади (професій) робітників, зайнятих обслуговуванням архівних установ», проте у процесі дослідження назву було скорочено до «Робітники». 3 цього розділу було видалено такі посади: готувач початкового матеріалу, копіювальник фільмових матеріалів 3, 4, 5, 6 розрядів, проявлювач кіноплівки 2, 3, 4, 5, 6 розрядів, реставратор фільмових матеріалів 2, 3, 4, 5 розрядів, установник кольору та світла $3,4,5,6$ розрядів. Ці посади застарілі, відсутні у штатних розписах та структурі архівних установ. Разом з тим, до нової редакції ДКХП було включено кваліфікаційну характеристику посади палітурник документів.

Кожна професійно-кваліфікаційна характеристика складається 3 таких розділів: «Завдання та обов’язки», «Повинен знати», «Кваліфікаційні вимоги».

У розділі «Завдання та обов'язки» наведено типові професійні завдання та обов'язки для певної посади, містять перелік основних робіт, які найчастіше трапляються, виходячи 3 розподілу і кооперації праці, що склалися у галузі. 
Конкретний перелік посадових обов'язків працівників визначається посадовими інструкціями, які розробляють i затверджують в архівах у встановленому порядку. Під час розроблення посадових інструкцій ураховуються конкретні завдання та обов'язки працівника, допускається уточнення переліку робіт, властивих відповідній посаді у конкретних організаційно-технічних умовах.

У розділі «Повинен знати» наводяться основні вимоги до спеціальних знань, необхідних працівникам архівних установ для виконання відповідних завдань та обов'язків, а також знання законодавчих актів, положень, інструкцій та інших нормативних документів, методів і засобів, які працівник повинен уміти застосовувати під час виконання посадових обов'язків.

У розділі «Кваліфікаційні вимоги» для кожної посади визначено вимоги до освітньо-кваліфікаційного рівня працівника архівів, необхідні для виконання покладених на нього завдань та обов'язків, мінімальні вимоги до стажу роботи та кваліфікації.

Для професійної групи «Керівники» типові професійні завдання, повноваження, вимоги до спеціальних знань визначено залежно від рівня та функцій управління i керівництва, які відрізняються за своєю складністю та відповідальністю. Поряд з роботами, що внесені до складу відповідного розділу кваліфікаційних характеристик посад, керівники повинні:

- володіти знаннями з права, економіки, адміністрування, фінансів, кадрових питань;

- аналізувати й узагальнювати інформацію, висловлювати нові ідеї, рішення, технології;

- розробляти планові матеріали, створювати можливості для майбутнього розвитку;

- забезпечувати умови для вдосконалення організації розподілу праці, виконання робіт та управління підрозділами;

- забезпечувати додержання вимог посадових інструкцій;

- удосконалювати форми мотивації праці працівників відповідно до їх професійних та ділових якостей, складності й умов праці, результатів діяльності організації; 
- застосовувати та впроваджувати новітні вітчизняні та зарубіжні досягнення у практику організації робіт.

Щодо кваліфікаційних вимог, то до професійної групи «Керівники» (керівник підрозділу, відділу) визначено вимогу повної вищої освіти відповідного напряму підготовки (магістр, спеціаліст) і стаж роботи за фахом - не менше 2 років. Для керівників (начальників, директорів) організацій - повна вища освіта відповідного напряму підготовки (магістр, спеціаліст). Післядипломна освіта в галузі управління. Стаж роботи за професіями керівників нижчого рівня - не менше 5 років.

Для професійної групи «Професіонали» ключовими $є$ вимоги повної вищої освіти 3 освітньо-кваліфікаційним рівнем - магістр, спеціаліст та чотирирівневе кваліфікаційне категоріювання. Поряд з роботами, що внесені до складу відповідного розділу кваліфікаційних характеристик посад, професіонали різних категорій повинні:

- вміти реалізовувати плани в межах своєї діяльності;

- систематизувати, аналізувати й обробляти інформацію;

- вживати заходів щодо усунення виявлених недоліків;

- знати основи використання комп'ютерної техніки;

- знати чинне законодавство в галузі архівної справи та діловодства.

Відповідно, кваліфікаційні вимоги, що використовуються для цієї професійної групи, розподіляються за категоріями (для прикладу візьмемо посаду «2.8 Палеограф (провідний палеограф, палеограф I категорії, палеограф II категорії, палеограф)»):

Провідний палеограф: вища освіта другого рівня за ступенем магістра відповідного напрямку підготовки. Стаж роботи за професією палеографа I категорії не менше 3 років. За наявності наукового ступеня доктора філософії з відповідної галузі знань - без вимог до стажу роботи.

Палеограф I категорії: вища освіта другого рівня за ступенем магістра відповідного напрямку підготовки. Стаж роботи за фахом палеографа II категорії не менше 2 років.

Палеограф II категорії: вища освіта першого рівня за ступенем бакалавра відповідного напрямку підготовки. Стаж роботи за професією палеографа не менше 2 років. 
Палеограф: вища освіта першого рівня за ступенем бакалавра відповідного напрямку підготовки. Без вимог до стажу роботи.

Для професійної групи «Технічні службовці» визначено вимоги професійно-технічної освіти чи повної загальної середньої освіти та професійної підготовки на виробництві, у сфері послуг. Крім того, представники цієї професійної групи повинні:

- знати основи роботи з комп'ютерною технікою;

- основи роботи на комп'ютері;

- правила та норми охорони праці;

- правила внутрішнього трудового розпорядку.

Для професій групи «Робітники», що виконують роботи високої та середньої складності, визначено кваліфікаційні вимоги повної чи базової загальної середньої освіти та професійно-технічної освіти або повної чи базової загальної середньої освіти та професійної підготовки на виробництві. Для професій робітників, що виконують найпростіші роботи, визначено вимоги базової загальної середньої освіти або початкової загальної освіти та професійне навчання на виробництві. Поряд з роботами, що внесені до відповідної кваліфікаційної характеристики професії, робітники повинні:

- раціонально та ефективно організовувати працю на робочому місці;

- дотримуватись норм технологічного процесу;

- знати й виконувати вимоги нормативних актів про охорону праці, дотримуватися норм, методів і прийомів безпечного ведення робіт.

Проте, варто зауважити, що у процесі вдосконалення організації праці, впровадження новітніх технологій можливе збільшення кількості обов'язків працівника, порівняно 3 встановленою кваліфікаційною характеристикою. У цих випадках працівнику може бути доручено виконання обов'язків, передбачених кваліфікаційними характеристиками працівників інших посад (професій), споріднених за складом робіт, рівних за складністю, виконання яких не потребує іншої спеціальної кваліфікації. 
Таким чином, у результаті проведеного дослідження було проаналізовано чинну нормативно-правову базу, яка регламентує організацію праці в архівних установах. На основі цього підготовлені кваліфікаційні характеристики професій працівників, зайнятих в архівній справі, застосування яких $\epsilon$ обов'язковим для встановлення кваліфікаційних розрядів (категорій) під час тарифікації робіт в архівних установах усіх галузей економіки. Досліджено особливості організації праці й управління в архівних установах та розглянуто зміст існуючих робіт (професій) працівників архівних установ, у результаті чого вилучено із практичної діяльності застарілі та введено нові види робіт. Здійснено перегляд, удосконалення чинних кваліфікаційних характеристик з урахуванням освоєння новітніх технологій в архівних установах та оновлено завдання і обов'язки працівників архівних установ кожної професійної групи. Зазначені матеріали викладено у новій редакції ДКХП. Випуск 81 «Культура та мистецтво». Розділ «Діяльність архівів».

Отримані результати дослідження можуть бути використані при розробленні посадових інструкцій працівників, що закріплює їхні обов'язки, права та відповідальність; складанні положень про структурні підрозділи, бо це визначає їхню роль та місце в системі управління підприємством (установою, організацією); формуванні та регулюванні ринку праці; при веденні документації про укладення трудового договору (прийняття на роботу), професійному просуванні, переведенні на іншу роботу, відстороненні від роботи, припиненні та розірванні трудового договору; присвоєнні й підвищенні категорій за посадою відповідно до оволодіння особою повним обсягом знань та робіт за результатами кваліфікаційної атестації; організації навчально-виховного процесу в закладах освіти, які готують працівників за професіями відповідних освітньокваліфікаційних рівнів.

\section{ДЖЕРЕЛА ТА ЛІТЕРАТУРА}

1. Конституція України: Закон України від 28.06.1996 № 254к/96-BP (із змінами i доповненнями). URL: http://zakon.rada.gov.ua (access 28.11.2018). 
2. Про зайнятість населення: Закон України від 05.07.2012 № 5067-VI (зі змінами). URL: http://zakon.rada.gov.ua/ laws/show/5067-17 (access 28.11.2018).

3. Про оплату праці [Електронний ресурс]: Закон України від 24.03.1995 № 108/95-BP (із змінами). URL: http:// zakon.rada.gov.ua/laws/ show/108/95-\%D0\%B2\%D1\%80 (access 03.12.2018).

4. Про охорону праці [Електронний ресурс]: Закон України від 14.10.1992 № 2694-XII (із змінами). URL: http://zakon.rada.gov.ua/laws/show/2694-12 (access 22.12.2018).

5. Про Національний архівний фонд та архівні установи [Електронний ресурс] : Закон України від 24.12.1993 № 3814XII (зі змінами). URL: https://zakon.rada.gov.ua/ laws/show/ 3814-12 (access 05.12.2018).

6. Про освіту [Електронний ресурс] : Закон України від 05.09. 2017 № 2145-VIII. URL: https://zakon.rada.gov.ua/ laws/show/2145-19 (access 18.12.2018).

7. Про вищу освіту [Електронний ресурс] : Закон України від 01.07.2014 № 1556-VII (зі змінами). URL: https://zakon.rada.gov.ua/laws/show/1556-18 (access 03.12.2018).

8. Про професійно-технічну освіту [Електронний ресурс] : Закон України від 10.02.1998 № 103/98-BP (зі змінами). URL: https://zakon.rada.gov.ua/laws/show/103/98-\%D0\%B2\%D1\%80 (access 18.12.2018).

9. Про затвердження Методичних рекомендацій щодо формування кваліфікаційних характеристик професій працівників [Електронний ресурс] : наказ М-ва соц. політики України та М-ва освіти і науки, молоді та спорту України від 16.12.2011 № 547/1438. URL: https://hrliga.com/docs/Nakaz_5471438.htm (access 03.12.2018).

10. Про затвердження Порядку розроблення та затвердження кваліфікаційних характеристик: наказ М-ва соц. політики України від 31.05 .2017 р. № 918 : зареєстр. в М-ві юстиції України 23 черв. 2017 р. за № 784/30652. URL: http://zakon.rada.gov.ua (access 22.12.2018).

11. Класифікатор професій ДК 003:2010: затв. наказом Держспоживстандарту України від 28.07.2010 № 327. URL: http:// zakon.rada.gov.ua/ rada/ show/ va327609-10 (access 28.11.2018). 
12. Довідник кваліфікаційних характеристик професій працівників. Вип. 81 : «Культура і мистецтво», розділ : «Діяльність архівів» / М-во праці та соц. політики України, Центр продуктивності, Держкомархів України, УНДІАСД ; [розробники: Н. М. Христова, Т. П. Прись]. Київ, 2008. 56 с. URL: http://undiasd.archives.gov.ua/doc/dov-kvalifik.pdf (access 03.12.2018).

13. Про умови оплати праці працівників архівних установ на основі Єдиної тарифної сітки: затв. Наказом Міністерства юстиції України; Схема від 15.11.2011 № 3327/5. URL: https://zakon.rada.gov.ua (access 22.12.2018).

\section{REFERENCES}

1. Konstytutsiia Ukrainy: Zakon Ukrainy vid 28.06.1996 № 254k/96-VR (iz zminamy i dopovnenniamy) [The Constitution of Ukraine: Law of Ukraine dated June 28, 1996 № 254к / 96-VR (with changes and additions)]. Retrieved from http://zakon.rada.gov.ua/laws/show/254\%D0\%BA/96$\% \mathrm{D} 0 \% \mathrm{~B} 2 \% \mathrm{D} 1 \% 80$ (Last accessed: 28.11.2018) [in Ukrainian].

2. Pro zainiatist naselennia: Zakon Ukrainy vid 05.07.2012 № 5067-VI (zi zminamy) [About employment of the population: Law of Ukraine dated 05.07.2012 № 5067-VI (with changes)]. Retrieved from http://zakon.rada.gov.ua (Last accessed: 28.11.2018) [in Ukrainian].

3. Pro oplatu pratsi: Zakon Ukrainy vid 24.03.1995 № 108/95$V R$ (iz zminamy) [About the payment of labor: Law of Ukraine dated March 24, 1995 № 108/95-VR (with changes)]. Retrieved from http://zakon.rada.gov.ua (Last accessed: 03.12.2018) [in Ukrainian].

4. Pro okhoronu pratsi: Zakon Ukrainy vid 14.10.1992 № 2694XII (iz zminamy) [About labor protection: Law of Ukraine dated October 14, 1992, № 2694-XII (with changes)]. Retrieved from http: //zakon.rada.gov.ua (Last accessed: 22.12.2018) [in Ukrainian].

5. Pro Natsionalnyi arkhivnyi fond ta arkhivni ustanovy: Zakon Ukrainy vid 24.12.1993 № 3814-XII (zi zminamy) [About the National Archival Fond and archival institutions: Law of Ukraine dated 24.12.1993 № 3814-XII (with changes)]. Retrieved from 
https: //zakon.rada.gov.ua/laws/show/3814-12 (Last accessed: 05.12.2018) [in Ukrainian].

6. Pro osvitu: Zakon Ukrainy vid 05.09. 2017 № 2145-VIII [About Education: Law of Ukraine dated 05.09. 2017 № 2145VIII]. Retrieved from https://zakon.rada.gov.ua/laws/show/2145-19 (Last accessed: 18.12.2018) [in Ukrainian].

7. Pro vyshchu osvitu: Zakon Ukrainy vid 01.07.2014 № 1556VII (zi zminamy) [About Higher Education: Law of Ukraine dated 01.07.2014 № 1556-VII (with changes).]. Retrieved from https://zakon.rada.gov.ua/laws/show/1556-18 (Last accessed: 03.12.2018) [in Ukrainian].

8. Pro profesiino-tekhnichnu osvitu: Zakon Ukrainy vid 10.02.1998 № 103/98-VR (zi zminamy) [About vocational-technical education: Law of Ukraine dated February 10, 1998 № 103/98-VR (with changes)]. Retrieved from https:// zakon.rada.gov.ua/ laws/show/103/98-\%D0\%B2\%D1\%80 (Last accessed: 18.12.2018) [in Ukrainian].

9. Pro zatverdzhennia Metodychnykh rekomendatsii shchodo formuvannia kvalifikatsiinykh kharakterystyk profesii pratsivnykiv: nakaz M-va sots. polityky Ukrainy ta M-va osvity i nauky, molodi ta sportu Ukrainy vid 16.12.2011 № 547/1438 [About the Approval of Methodical Recommendations for the Formation of Qualification Characteristics of the Employees Occupations: Order of the Ministry of Social Policy and and the Ministry of Education and Science, Youth and Sports of Ukraine dated 16.12.2011 № 547/1438]. Retrieved from https://hrliga.com/docs/Nakaz_5471438.htm (Last accessed: 03.12.2018) [in Ukrainian].

10. Pro zatverdzhennia Poriadku rozroblennia ta zatverdzhennia kvalifikatsiinykh kharakterystyk: nakaz M-va sots. polityky Ukrainy vid 31.05.2017 r. № 918 [About the Approval of the Procedure for the Development and Approval of Qualification Characteristics: Order of the Ministry of Social Policy of Ukraine dated 31.05.2017 № 918]. Retrieved from http://zakon.rada.gov.ua (Last accessed: 22.12.2018) [in Ukrainian].

11. Klasyfikator profesii DK 003:2010: zatv. nakazom Derzhspozhyvstandartu Ukrainy vid 28.07.2010 № 327 [Classifier of professions DK 003: 2010: the Order of Derzhspozhyvstandart of Ukraine dated 07/28/2010 № 327]. Retrieved from http://zakon.rada.gov.ua (Last accessed: 28.11.2018) [in Ukrainian]. 
12. Dovidnyk kvalifikatsiinykh kharakterystyk profesii pratsivnykiv [Handbook of qualification characteristics of employees professions]. Retrieved from http:// undiasd.archives.gov.ua/doc/dov-kvalifik.pdf (Last accessed: 03.12.2018) [in Ukrainian].

13. Pro umovy oplaty pratsi pratsivnykiv arkhivnykh ustanov na osnovi Yedynoi taryfnoi sitky: zatv. Nakazom Ministerstva yustytsii Ukrainy; Skhema vid 15.11.2011 № 3327/5 [About the conditions of archival institutions workers payment based on Unified tariff: approved by the Order of the Ministry of Justice of Ukraine; Scheme from 15.11.2011 № 3327/5]. Retrieved from https://zakon.rada.gov.ua (Last accessed: 22.12.2018) [in Ukrainian].

\section{АНОТАЦІЯ}

У статті проаналізовано нормативно-правові, науковометодичні та законодавчі документи, положення яких регламентують діяльність архівних установ Украӥни. Досліджено особливості організащіï праці й управління в архівних установах, зміст існуючих професій їхніх працівників. Вивчено сучасні зміни в архівних технологіях, умовах організації працฺі та вимогах до професійно-кваліфікаційних рівнів прачівників. За результатами визначено застарілі види робіт, щуо не проводяться в архівах (проявлення кіноплівки, встановлення світла та кольору при обробці фільмокопій, підготовка вихідних матеріалів фільмів). Складено перелік нових видів архівної діяльності, продиктованих змінами в підходах до організачії роботи та використання робочого часу, продуктивнішої співпраці архівістів та користувачів архівів, ефективного захисту електронних архівних документів (знання основ використання комп 'ютерної техніки, однієї чи кількох іноземних мов, володіння знаннями з права, економіки, адміністрування, фінансів, використання новітнього вітчизняного та зарубіжного досвіду). Визначено особливості змісту існуючих та нових видів робіт (професій) працівників архівної сфери. Сформовано перелік основних кваліфікаційних характеристик професій працівників, зайнятих в архівній справі та встановлено, щуо їхнє застосування є обов'язковим 
для присвоєння кваліфікаиійних розрядів (категорій), визначає основні роботи, властиві тій або іншій посаді (професії), забезпечує єдність у визначенні кваліфікаційних вимог до певних посад (професій), дає змогу оитінти повноту відповідності змісту та якості виконання робіт працівником на певній посаді (певної професії) відповідної категорії під час кваліфікаційних випробувань. Запропоновано власне бачення завдань і обов'язків, кваліфікачійних вимог та вимог до рівня знань для посад (професій) працівників архівних установ. На основі ицього розроблено нову редакцію нормативного документа, щзо є обов'язковим для використання в архівних установах - Довідника кваліфікаційних характеристик професій працівників. Випуск 81 «Культура та мистецтво». Розділ "Діяльність архівів».

Ключові слова: архівна установа, Довідник, документ, характеристика, вимоги, посада, працівник.

\section{АННОТАЦИЯ}

В статье проанализированы нормативно-правовые, научно-методические и законодательные документы, положения которых регламентируют деятельность архивных учреждений Украины. Исследованы особенности организачии труда и управления в архивных учреждениях, содержание существуюших профессий их работников. Изучень современные изменения в архивных технологиях, условиях организации труда и требованиях $к$ профессиональноквалификачионным уровням работников. По результатам определены устаревшие виды работ, которые не проводятся в архивах (проявка кинопленки, установка света и цвета при обработке фильмокопий, подготовка исходных материалов фильмов). Составлен перечень новых видов архивной деятельности, продиктованных изменениями в подходах к организации работы и использования рабочего времени, более продуктивного сотрудничества архивистов и пользователей архивов, эффективной защчтыь электронных архивных документов (знание основ использования компьютерной техники, одного или нескольких иностранных языков, владение знаниями по праву, экономике, администрированию, финансах, 
использование новейшего отечественного и зарубежного опыта). Определены особенности содержания сущзествующих и новых видов работ (профессий) работников архивной сферы. Сформирован перечень основных квалификационных характеристик профессий работников, занятых в архивном деле. Установлено, что их применение является обязательным для присвоения квалификационных разрядов (категорий), а также определяет основныле работы, присущче той или иной должности (профессии), обеспечивает единство в определении квалификационных требований к определенным должностям (профессиям), позволяет оценить полноту соответствия содержания и качества выполнения работ работником определенной должности (определенной профессии), соответствующей категории во время квалификационных испытаний. Предложено собственное видение задач и обязанностей, квалификационных требований и требований к уровню знаний для должностей (профессий) работников архивных учреждений. На основе этого разработана новая редакция нормативного документа, являющегося обязательным для использования в архивных учреждениях Справочника квалификационных характеристик профессий работников. Выпуск 81 «Культура и искусство». Раздел "Деятельность архивов".

Ключевые слова: архивное учреждение, Справочник, документ, характеристика, требования, должность, работник. 